\title{
ANALISIS BEBAN KERJA TENAGA GIZI DI RSUD BANJARBARU
}

\author{
Analysis Work Load Power Nutrition in Hospital Banjarbaru \\ Maidina Aisyah, Aprianti, Rusmini Yanti \\ Poltekkes Kemenkes Banjarmasin \\ apriantichalidi@yahoo.com
}

\begin{abstract}
The better nutrition services provided by hospitals, the better the hospital's accreditation standards. The purpose of this study was conducted to analyze the work of nutrition workers in the Banjarbaru District General Hospital Nutrition. This research is observational research which is descriptive qualitative. The population in this study is the whole power of nutrition in hospitals Banjarbaru totaling 9 people. Analysis of the data presented in descriptive. The results of this study the productive use of time energy malnutrition in the inpatient unit of $60.6 \%$, while in the room holding $94 \%$, the time available for personnel working in inpatient nutrition at 34.25 hours/week while in the implementation of food 35 hours/week. Standard workload nutritional power per show each activity takes every appropriate standard workload of weekday activities available. The proportion of time workload energy malnutrition in the inpatient unit is less than the standard, while in the implementation of the food exceeds the standards of productive time and working time available power is not appropriate nutrition. Expected to pursue further research to determine the standard of leniency and labor requirements at another hospital or other place.
\end{abstract}

Keywords: Workload, nutritionists, dietician, food service

\begin{abstract}
Abstrak
Semakin baik pelayanan gizi yang diberikan oleh rumah sakit, maka semakin baik pula standar akreditasi rumah sakit tersebut. Tujuan penelitian ini dilakukan untuk menganalisis beban kerja tenaga gizi di Instalasi Gizi RSUD Banjarbaru. Penelitian ini merupakan penelitian observasional yang bersifat deskriptif kualiatif. Populasi dalam penelitian ini adalah seluruh tenaga gizi di RSUD Banjarbaru yang berjumlah 9 orang. Analisis data disajikan dalam bentuk deskriptif. Hasil penelitian ini Penggunaan waktu produkif tenaga gizi di ruang rawat inap 60,6\% sedangkan di ruang penyelenggaraan 94\%, waktu kerja yang tersedia bagi tenaga gizi di ruang rawat inap sebesar 34,25 jam/minggu sedangkan di ruang penyelenggaraan makanan 35 jam/minggu. Standar beban kerja tenaga gizi pertahun menunjukkan setiap kegiatan membutuhkan waktu dalam setiap standar beban kerja sesuai kegiatan dari hari kerja yang tersedia. Proporsi waktu beban kerja tenaga gizi di ruang rawat inap kurang dari standar sedangkan di ruang penyelenggaraan makanan melebihi standar waktu produktif dan waktu kerja yang tersedia tenaga gizi belum sesuai. Diharapkan dapat melanjutkan penelitian selanjutnya untuk menentukan standar kelonggaran dan kebutuhan tenaga kerja di rumah sakit lain atau ditempat lainnya.
\end{abstract}

Kata kunci : Beban kerja, ahli gizi, dietisien, penyelenggaraan makanan 


\section{PENDAHULUAN}

Menurut Depkes RI (2003), rumah sakit merupakan salah satu sarana kesehatan yang memberikan pelayanan kesehatan kepada masyarakat. Pelayanan yang diberikan ditujukan untuk pemulihan pasiennya dengan tidak mengabaikan peran lainnya untuk promotif, prevenif, dan rehabilitatif, salah satunya melalui kegiatan pelayanan gizi di rumah sakit.

Agar kegiatan asuhan gizi berjalan optimal, diperlukan tenaga kesehatan yang memadai baik dari segi kualitas maupun kuantitasnya. Ahli gizi merupakan salah satu tenaga dari anggota tim kesehatan yang sangat berperan dalam asuhan gizi pasien (Rachmat, 2003).

Semakin baik pelayanan gizi yang diberikan oleh rumah sakit, maka semakin baik pula standar akreditasi rumah sakit tersebut. Hal ini dapat terlaksana bila tersedia tenaga gizi yang profesional dalam memberikan pelayanan gizi. Profesionalisme tenaga gizi dalam memberikan pelayanan gizi diatur berdasarkan Permenkes No 26 tahun 2013, tentang Penyelenggaraan Pekerjaan dan Praktek Tenaga Gizi. Dalam upaya menjamin pelaksanaan pelayanan gizi yang optimal di rumah sakit diperlukan adanya standar kebutuhan tenaga gizi secara lebih rinci yang memuat jenis dan jumlah tenaga gizi (Depkes RI, 2013).

Suharyono dan wiku (2006) melakukan penelitian kebutuhan tenaga pekarya di unit layanan gizi pelayanan kesehatan menggunakan metode work sampling didapat hasil shift kerja adalah $43,57 \%$ dan penggunaan waktu produktif terhadap total waktu kegiatan dalam satu hari kerja 53,36 \%. Kegiatan langsung tenaga pekarya di layanan gizi Pelayanan Kesehatan Sint Carolus pada waktu pagi hari $24,93 \%$, sedangkan pada waktu kerja sore lebih rendah sebesar 17,94\%. Dapat disimpulkan bahwa penggunaan waktu produktif tenaga pekarya masih rendah. Berdasarkan penggunaan waktu produktif dibutuhkan 8 tenaga pekarya, dan berdasarkan metode WISN hanya dibutuhkan 7 tenaga pekarya.
Hendrorini (2012) melakukan penelitian beban kerja tenaga gizi yang bekerja di Unit Produksi Makanan dan di Ruang Rawat Inap pada beberapa Rumah Sakit di Jabodetabek menggunakan metode time study didapat hasil < $90 \%$ dari jam kerja efektif sehari (360 menit) namun responden D4/S1 Gizi yang bekerja di produksi makanan mempunyai beban kerja cukup; di unit produksi makanan beban kerja lebih banyak pada responden lulusan D3/S1 non Gizi dibanding D4/S1 Gizi; Responden yang bekerja tidak sesuai uraian tugas dan tidak sesuai kompetensi dengan beban kerja lebih banyak pada lulusan D3/S1 non Gizi dibanding lulusan D4/S1 Gizi. Penelitian ini menyimpulkan bahwa responden lebih banyak yang bekerja tidak sesuai uraian tugas, tidak sesuai kompetensi dan beban kerja kurang; tidak terlihat adanya kecenderungan hubungan antara perbedaan jenis kelamin, masa kerja, umur, uraian tugas dengan beban kerja; hampir semua uraian tugas yang ada di rumah sakit tempat penelitian belum dapat mengukur beban kerja, belum semua kompetensi yang harus dilakukan sudah tercakup dalam uraian tugas dan beban kerja.

Rumah Sakit Umum Daerah Banjarbaru berkelas C terakreditasi 12 pokja sejak tahun 2005 dengan nomor registrasi akreditasi KARSSERT/198/XI/ 2012 dengan masa berlaku 9 Desember 2012 s/d 9 Desember 2014. RSUD Banjarbaru mempunyai kapasitas tempat tidur 137 degan BOR $89,86 \%$ pada tahun 2014. Peraturan terbaru kapasitas tempat tidur pada tahun 2015 yaitu 184 TT. Berdasarkan buku pedoman PGRS tahun 1991, perhitungan kebutuhan ahli gizi di rumah sakit dengan menggunakan rasio tempat tidur pasien. Kebutuhan ahli gizi di ruang rawat inap 1:100 untuk sarjana muda gizi 1:400.

Rumah sakit tipe $C$ kebutuhan tenaga gizinya sebanyak 30 orang, sedangkan di Rumah Sakit Umum Daerah Banjarbaru hanya memiliki 9 orang tenaga gizi. Kekurangan tenaga kerja akan berakibat pada besarnya beban kerja yang melebihi kemampuan tenaga kerja, sehingga menjadi tidak efekif karena hanya ditangani oleh beberapa orang tertentu yang 
mengakibatkan tidak tercapainya pelayanan yang memuaskan.

\section{BAHAN DAN METODE}

Jenis Penelitian ini merupakan penelitian observasional yang bersifat deskripif untuk mengetahui beban kerja tenaga gizi. Penelitian ini dilaksanakan di Rumah Sakit Umum Daerah Banjarbaru, pada bulan Februari - Juni tahun 2016. Populasi dari penelitian ini adalah semua tenaga gizi di Rumah Sakit Umum Daerah Banjarbaru, sedangkan Sampel penelitian ini adalah tenaga gizi di Rumah Sakit Umum Daerah Banjarbaru yang ada di ruang penyelenggaraan makanan 3 orang dan di ruang rawat inap berjumlah 4 orang. Data primer penelitian ini adalah beban kerja, waktu kerja yang tersedia, dan standar beban kerja tenaga gizi di ruang rawat inap dan ruang penyelengaraan makanan. Pengolahan data beban kerja dengan rumus sebagai berikut : $\mathrm{p}=\frac{\mathrm{n}}{\mathrm{N}} \times 100 \%$

Pengolahan data waktu kerja tersedia dengan rumus sebagai berikut : Waktu Kerja Tersedia $=\{\mathrm{A}-$ $(\mathrm{B}+\mathrm{C}+\mathrm{D}+\mathrm{E})\} \times \mathrm{F}$

Pengolahan data standar beban kerja dengan rumus sebagai berikut :

Standar beban kerja: $\frac{\text { Waktu kerja yang tersedia pertahun }}{\text { Satuan waktu perkegiatan pokok }}$

\section{HASIL DAN PEMBAHASAN \\ Besar Beban Kerja Tenaga Gizi}

Berdasarkan hasil pengamatan work sampling, bahwa penggunaan waktu produkif tenaga gizi di ruang rawat inap sebanyak 4 orang terhadap total waktu dalam satu hari kerja yaitu $60,6 \%$ yang didapat dari penjumlahan persentase kegiatan langsung $31,7 \%$ dan tidak langsung 28,9\%, sedangkan penggunaan waktu produkif tenaga gizi diruang penyelenggaraan makanan sebanyak 3 orang terhadap total waktu dalam satu hari kerja yaitu $94 \%$ yang didapat dari jumlah persentase kegiatan tidak langsung.

Penggunaan waktu produktif tenaga gizi diruang rawat inap terhadap total waktu dalam satu hari kerja yaitu 60,6\%. Proporsi waktu beban kerja tenaga gizi ruang rawat inap RSUD Banjarbaru kurang dari standar waktu kerja produktif. Hal ini dikarenakan pada saat penelitian ada seorang ahli gizi yang melakukan kegiatan nonproduktif (aktivitas yang sama sekali tidak terkait dengan kegiatan pokok dan penunjang fungsi unit dan tidak bermanfaat bagi unit pelayanan) seperti ikut membagi snack dan makan pasien ke ruangan yang seharusnya dilakukan oleh pramusaji. Kegiatan ahli gizi di ruang rawat inap RSUD Banjarbaru sebenarnya sudah sesuai dengan menurut Kemenkes RI (2013), untuk mengisi jam kerja yang kosong sehingga ada ahli gizi yang ikut membagi snack dan makan pasien. Setiap ruangan yang ada di RSUD Banjarbaru memiliki 1 orang ahli gizi, sehingga beban kerja ahli gizi tidak terlalu besar.

Proporsi waktu beban kerja tenaga gizi di ruang penyelenggaraan makanan melebihi dari standar waktu kerja produktif. Menurut Ilyas (2004) menyatakan bahwa waktu kerja yang produktif berkisar $80 \%$, maka dari itu perlu adanya penambahan tenaga gizi. Tetapi, RSUD Banjarbaru menerima tenaga kerja gizi yang baru hanya saja tidak masuk dalam penelitian karena waktu kerjanya belum mencapai 1 tahun. Ahli gizi di RSUD Banjarbaru melakukan kegiatan sesuai tugasnya masing-masing, dengan beban kerja yang berlebih, ahli gizi di RSUD Banjarbaru kegiatan penyelenggaraan makanan dapat teratasi dan berjalan dengan lancar.

\section{Waktu Kerja Tersedia}

Tabel 1. Waktu Kerja Tersedia Tenaga Gizi di Ruang Rawat Inap RSUD Banjarbaru

\begin{tabular}{|c|c|c|c|}
\hline Kode & Faktor & Jumlah & Keterangan \\
\hline A & $\begin{array}{l}\text { Hari Kerja } \\
\text { ( } 25 \text { hari sebulan } \\
\text { x } 12 \text { bulan) }\end{array}$ & 300 & Hari/Tahun \\
\hline B & Cuti Tahunan & 7 & Hari/Tahun \\
\hline C & $\begin{array}{l}\text { Pendidikan dan } \\
\text { Pelatihan }\end{array}$ & 1 & Hari/Tahun \\
\hline $\mathrm{D}$ & $\begin{array}{l}\text { Hari Libur } \\
\text { Nasional } \\
\text { Rata-rata }\end{array}$ & 16 & Hari/Tahun \\
\hline E & $\begin{array}{l}\text { ketidakhadiran } \\
\text { kerja }\end{array}$ & 2 & Hari/Tahun \\
\hline \multirow[t]{4}{*}{$\mathrm{F}$} & $\begin{array}{l}\text { Waktu kerja } \\
\text { sehari }\end{array}$ & 6 & Jam/Hari \\
\hline & $\begin{array}{l}\text { Hari kerja } \\
\text { tersedia }\end{array}$ & 274 & $\begin{array}{c}\text { Hari } \\
\text { kerja/Tahun }\end{array}$ \\
\hline & $\begin{array}{l}\text { Waktu kerja } \\
\text { tersedia }\end{array}$ & 1644 & $\begin{array}{c}\text { Jam } \\
\text { kerja/Tahun }\end{array}$ \\
\hline & & 98640 & Menit/tahun \\
\hline
\end{tabular}


Berdasarkan tabel 1 dapat diketahui bahwa waktu kerja tersedia bagi ahli gizi di ruang rawat inap RSUD Banjarbaru sebesar 34,25 jam/minggu.

Tabel 2. Waktu Kerja Tersedia Tenaga Gizi di Ruang Penyelenggaraan Makanan RSUD Banjarbaru

\begin{tabular}{|c|c|c|c|}
\hline Kode & Faktor & Jumlah & Keterangan \\
\hline A & $\begin{array}{l}\text { Hari Kerja } \\
\text { ( } 25 \text { hari sebulan } \\
\text { x } 12 \text { bulan) }\end{array}$ & 300 & Hari/Tahun \\
\hline B & Cuti Tahunan & 3 & Hari/Tahun \\
\hline $\mathrm{C}$ & $\begin{array}{l}\text { Pendidikan dan } \\
\text { Pelatihan }\end{array}$ & 1 & Hari/Tahun \\
\hline $\mathrm{D}$ & $\begin{array}{l}\text { Hari Libur } \\
\text { Nasional } \\
\text { Rata-rata }\end{array}$ & 16 & Hari/Tahun \\
\hline $\mathrm{E}$ & $\begin{array}{l}\text { ketidakhadiran } \\
\text { kerja }\end{array}$ & - & Hari/Tahun \\
\hline \multirow[t]{4}{*}{$\mathrm{F}$} & $\begin{array}{l}\text { Waktu kerja } \\
\text { sehari }\end{array}$ & 6 & Jam/Hari \\
\hline & $\begin{array}{l}\text { Hari kerja } \\
\text { tersedia }\end{array}$ & 280 & $\begin{array}{c}\text { Hari } \\
\text { kerja/Tahun }\end{array}$ \\
\hline & $\begin{array}{l}\text { Waktu kerja } \\
\text { tersedia }\end{array}$ & 1680 & $\begin{array}{c}\text { Jam } \\
\text { kerja/Tahun }\end{array}$ \\
\hline & & 100,800 & Menit/Tahun \\
\hline
\end{tabular}

Berdasarkan tabel 2 dapat diketahui bahwa waktu kerja tersedia bagi ahli gizi di ruang penyelenggaraan makanan RSUD Banjarbaru sebesar 35 jam/minggu.

Berdasarkan data yang didapat waktu kerja yang tersedia di RSUD Banjarbaru dapat dikatakan belum sesuai karena masih kurang dari 37,5 jam perminggu. Hal ini dikarenakan waktu kerja yang ditetapkan di RSUD Banjarbaru lebih pendek yaitu hanya 6 jam perhari dari jam 07.30-14.30 WITA. Menurut Susetyowati (2003) dalam Purnamasari (2010) jam kerja ahli gizi dalam sehari adalah 6,2 jam perhari. Tugas ahli gizi ruangan memang tidak sebanyak tugas perawat, dokter dan yang lain, sehingga dalam waktu kerja 6 jam pun seorang ahli gizi mampu menyelesaikan tugasnya apalagi bila pasien tidak terlalu banyak.

\section{Standar Beban Kerja}

Tabel 3. Standar beban kerja tenaga gizi di ruang rawat inap RSUD Banjarbaru

\begin{tabular}{|c|c|c|c|}
\hline No. & $\begin{array}{c}\text { Standar Beban Kerja } \\
\text { Tenaga Gizi Ruang } \\
\text { Rawat Inap }\end{array}$ & $\begin{array}{c}\text { Rata- } \\
\text { rata } \\
\text { waktu } \\
\text { (menit) }\end{array}$ & $\begin{array}{c}\text { Standar } \\
\text { Beban } \\
\text { Kerja }\end{array}$ \\
\hline 1. & $\begin{array}{l}\text { Mengkaji hasil } \\
\text { skrining gizi perawat } \\
\text { dan order diet awal } \\
\text { dari dokter. }\end{array}$ & 10 & 9864 \\
\hline 2. & $\begin{array}{l}\text { Melakukan } \\
\text { asesmen/pengkajian }\end{array}$ & 15 & 6576 \\
\hline 3. & $\begin{array}{l}\text { Menganalisa dan } \\
\text { interpretasi data } \\
\text { riwayat gizi dan } \\
\text { personal }\end{array}$ & 10 & 9864 \\
\hline 4. & $\begin{array}{l}\text { Melakukan } \\
\text { pengukuran } \\
\text { antropometri }\end{array}$ & 10 & 9864 \\
\hline 5. & $\begin{array}{l}\text { Menganalisa hasil } \\
\text { laboratorium terkait } \\
\text { gizi }\end{array}$ & 5 & 19728 \\
\hline 6. & $\begin{array}{l}\text { Menganalisa hasil } \\
\text { pemeriksaan fisik }\end{array}$ & 5 & 19728 \\
\hline 7. & $\begin{array}{l}\text { Mengidentifikasi } \\
\text { masalah/ diagnosa } \\
\text { gizi. }\end{array}$ & 10 & 9864 \\
\hline 8. & $\begin{array}{l}\text { Merancang intervensi } \\
\text { gizi dengan } \\
\text { menetapkan tujuan } \\
\text { dan preskripsi diet } \\
\text { yang terperinci untuk } \\
\text { penetapan diet serta } \\
\text { merencanakan edukasi } \\
\text { / konseling. }\end{array}$ & 20 & 4932 \\
\hline 9. & $\begin{array}{l}\text { Melakukan koordinasi } \\
\text { dengan dokter terkait } \\
\text { dengan diet. }\end{array}$ & 20 & 4932 \\
\hline 10. & $\begin{array}{l}\text { Koordinasi dengan } \\
\text { dokter, perawat, } \\
\text { farmasi, dan tenaga } \\
\text { lain dalam } \\
\text { pelaksanaan intervensi } \\
\text { gizi }\end{array}$ & 20 & 4932 \\
\hline 11. & $\begin{array}{l}\text { Melakukan } \\
\text { monitoring respon } \\
\text { pasien terhadap } \\
\text { intervensi gizi }\end{array}$ & 15 & 6576 \\
\hline 12. & $\begin{array}{l}\text { Melakukan evaluasi } \\
\text { proses maupun } \\
\text { dampak asuhan gizi }\end{array}$ & 15 & 6576 \\
\hline 13. & $\begin{array}{l}\text { Memberikan } \\
\text { penyuluhan, motivasi, } \\
\text { dan konseling gizi } \\
\text { pada klien/pasien dan } \\
\text { keluarganya. }\end{array}$ & 25 & 3945,6 \\
\hline
\end{tabular}




\begin{tabular}{|c|c|c|c|}
\hline 14. & $\begin{array}{l}\text { Mencatat dan } \\
\text { melaporkan hasil } \\
\text { asuhan gizi kepada } \\
\text { dokter }\end{array}$ & 10 & 9864 \\
\hline 15. & $\begin{array}{l}\text { Melakukan assesmen } \\
\text { gizi ulang } \\
\text { (reassesment) apabila } \\
\text { tujuan belum tercapai. } \\
\text { Mengikuti ronde }\end{array}$ & 10 & 9864 \\
\hline 16. & $\begin{array}{l}\text { pasien bersama tim } \\
\text { kesehatan. }\end{array}$ & 40 & 2466 \\
\hline 17. & $\begin{array}{l}\text { Berpartisipasi aktif } \\
\text { dalam pertemuan atau } \\
\text { diskusi dengan dokter, } \\
\text { perawat, anggota tim } \\
\text { asuhan gizi lain, } \\
\text { klien/pasien dan } \\
\text { keluarganya dalam } \\
\text { rangka evaluasi } \\
\text { keberhasilan } \\
\text { pelayanan gizi }\end{array}$ & 20 & 4932 \\
\hline
\end{tabular}

Berdasarkan tabel 3 diketahui bahwa waktu kerja tenaga gizi di ruang rawat inap maksimum 40 menit dengan standar beban kerja 2466 pada kegiatan mengikuti ronde pasien bersama tim kesehatan, sedangkan waktu minimum adalah 5 menit dengan standar beban kerja 19728 pada kegiatan menganalisa hasil laboratorium terkait gizi dan menganalisa hasil pemeriksaan fisik.

Tabel 4. Standar beban kerja tenaga gizi di ruang penyelenggaraan makanan RSUD Banjarbaru

\begin{tabular}{llll}
\hline No. $\quad \begin{array}{l}\text { Standar Beban } \\
\text { Kerja (Ruang } \\
\text { Penyelenggaraan } \\
\text { Makanan) }\end{array}$ & $\begin{array}{c}\text { Rata- } \\
\text { rata } \\
\text { waktu } \\
\text { (menit) }\end{array}$ & $\begin{array}{c}\text { Standar } \\
\text { Beban } \\
\text { Kerja }\end{array}$ \\
\hline $\begin{array}{l}\text { Menyusun rencana } \\
\text { pedoman menu } \\
\text { bersama dengan } \\
\text { pihak penyelenggara } \\
\text { makanan }\end{array}$ & 30 & 3360 \\
Melaksanakan \\
pembukaan bon \\
baru, pembatalan \\
dan hari makan \\
pasien \\
Melaksanakan \\
pencatatan dan \\
pelaporan pelayanan \\
makanan secara \\
tertib, dan benar, \\
meliputi data hari \\
makan, jenis diet,
\end{tabular}

jumlah porsi, bon

baru, pembatalan

makanan dsb

Crosscheck jumlah

makan porsi pasien

20

5040

Pengawasan dan

pengendalian mutu

5. pelayanan makanan

meliputi jumlah

porsi, kesesuaian

menu dan diet

Pengelolaan

kegiatan

pemantauan mutu

6. makanan dan

120

melakukan

pengawasan mutu makanan

Melakukan evaluasi

dan analisis mutu

7. pelayanan makanan

sesuai hasil

pemantauan

Melakukan

pengawasan dan

ikut serta dalam

kegiatan hygiene

8. sanitasi lingkungan

dan peralaatan

30

pantry, pemeriksaan

hyigene perorangan

tenaga penjamah

makanan

Menyusun laporan

9. evaluasi pelayanan

makanan setiap

120

bulan

Menyusun

rekomendasi

10. evaluasi pelayanan $30 \quad 3360$

makanan setiap 3

bulan

Melakasanakan

pencatatan dan pelaporan kerusakan dan perbaikan alat / sarana pelayanan

11. makanan dan 520160 melaporkan kepada petugas inventarisasi alat
840

3360

840

6720

10080

720

(1)

(20160

Berdasarkan tabel 4 diketahui bahwa waktu kerja tenaga gizi di ruang penyelenggaraan makanan 
RSUD Banjarbaru maksimum 120 menit dengan standar beban kerja 840 pada kegiatan pengelolaan kegiatan pemantauan mutu makanan dan melakukan pengawasan mutu makanan dan menyusun laporan evaluasi pelayanan makanan setiap bulan, sedangkan waktu minimum adalah 5 menit dengan standar beban kerja 20160 pada kegiatan melakasanakan pencatatan dan pelaporan kerusakan dan perbaikan alat/sarana pelayanan makanan dan melaporkan kepada petugas inventarisasi alat.

Berdasarkan penelitian yang sudah dilakukan diketahui ahli gizi di ruang rawat inap memiliki beban kerja kurang dan ahli gizi yang ada di ruang penyelenggaraan makanan memiliki beban kerja berlebih. Kebutuhan tenaga ahli gizi berdasarkan rasio tempat tidur untuk rumah sakit tipe $C$ yaitu 1 : 25. RSUD Banjarbaru memiliki kapasitas tempat tidur 184 dibutuhkan 8 orang ahli gizi, sedangkan pada kenyataannya ahli gizi yang ada 9 orang, sehingga seluruh kegiatan ahli gizi yang ada di rumah sakit Banjarbaru dapat dikerjakan dengan lancar.

\section{KESIMPULAN DAN SARAN}

Penggunaan waktu produktif tenaga gizi diruang rawat inap masih kurang dan di ruang penyelenggaraan makanan melebihi dari standar. Waktu kerja yang tersedia belum sesuai dengan standar yang ditentukan. Standar beban kerja pertahun menunjukkan setiap kegiatan membutuhkan waktu dalam setiap standar beban kerja sesuai kegiatan. Diharapkan dapat melanjutkan penelitian selanjutnya untuk menentukan standar kelonggaran dan kebutuhan tenaga kerja di rumah sakit lain atau ditempat lainnya.

\section{DAFTAR PUSTAKA}

Depkes RI, 1991. Pelayanan Gizi Rumah Sakit (PGRS). Jakarta: Direkorat Gizi Masyarakat.

Depkes RI, 2003. Pelayanan Gizi Rumah Sakit (PGRS). Jakarta: Direkorat Gizi Masyarakat.

Departemen Kesehatan RI, 2013, Buku pedoman Pelayanan Gizi Rumah Sakit, Dirjen Pelayanan Medik, Direktorat Rumah Sakit khusus dan Swasta, Jakarta.

Hendrorini, A., I. Anwar., dan E. Herianandita. 2012. Analisis Beban Kerja Tenaga Gizi Yang Bekerja Di Unit Produksi Makanan Dan Di Ruang Rawat Inap Pada Beberapa Rumah Sakit Di Jabodetabek Tahun 2012

Ilyas, Y., 2004. Perencanaan SDM Rumah Sakit : Teori, Metoda, dan Formula. Depok, FKM-UI.

Kemenkes RI., 2013. Pelayanan Gizi Rumah Sakit. Available form: http://gizi.depkes.go.id/download/Pedoman \%20Gizi/COVER\%20PGRS_PGRS\%20Final.pd f [Accessed 11 januari 2016].

M. Waseso Suharyono, Wiku B.B Adisasmito. 2006. "Analisis Jumlah Kebutuhan. Tenaga Pekarya Dengan Work Sampling di Unit Layanan Gizi Pelayanan.

Purnamasari S. I., 2010. Analaisa Kebutuhan enaga Ahli Gizi Berdsarkan Beban Kerja di RSUD Banjarmasin : Banjarmasin.

Rachmat, H. H., 2003. Kebijakan Pengembangan Tenaga Kesehatan Dan Perencanaan Pengembangan Sumberdaya Manusia Kesehatan. Yogyakarta: Lokakarya pengembangan SDM RS Sardjito. 